\title{
Complement mediators: key regulators of airway tissue remodeling in asthma
}

\author{
Mohammad Afzal Khan ${ }^{1 *}$, Abdullah Mohammed Assiri ${ }^{1}$ and Dieter Clemens Broering ${ }^{2}$
}

\begin{abstract}
The complement mediators are the major effectors of the immune balance, which operates at the interface between the innate and adaptive immunity, and is vital for many immunoregulatory functions. Activation of the complement cascade through the classical, alternative or lectin pathways thus generating opsonins like C3b and C5b, anaphylatoxins $\mathrm{C} 3 \mathrm{a}$ and $\mathrm{C} 5 \mathrm{a}$, chemotaxin, and inflammatory mediators, which leads to cellular death. Complement mediators that accelerate the airway remodeling are not well defined; however, an uncontrolled Th2-driven adaptive immune response has been linked to the major pathophysiologic features of asthma, including bronchoconstriction, airway hyperresponsiveness, and airway inflammation. The mechanisms leading to complement mediated airway tissue remodeling, and the effect of therapy on preventing and/or reversing it are not clearly understood. This review highlights complement-mediated inflammation, and the mechanism through it triggers the airway tissue injury and remodeling in the airway epithelium that could serve as potential targets for developing a new drug to rescue the asthma patients.
\end{abstract}

Keywords: Complement mediators, Airway remodeling, Anaphylatoxins

\section{Introduction}

Asthma is a chronic inflammatory disease of the airways distinguished by the variable airflow obstruction and associated increase in airway hyperresponsiveness (AHR) to various stimuli [1-3]. Asthma is considered to be mediated primarily by the allergen-specific $\mathrm{CD} 4^{+} \mathrm{T}$ cells, Th2 cytokines, and allergen-specific IgE antibody leading to airway inflammation and hyperresponsiveness [4-7]. Cellular inflammation of the diseased airways with eosinophil and neutrophil is the hallmark feature of asthma and is considered relevant to the pathogenesis of the disease [8-10]. Asthma pathogenesis has been associated with major pathophysiologic features including airway constriction, hyperresponsiveness, and neutrophilic inflammation [11-14] (Figs. 1, 2). In addition, overactivated complement cascade play a key role as effectors of cell-mediated and humoral immune system in pulmonary tissue injury during asthma pathogenesis [15-17].

\footnotetext{
*Correspondence: mkhan26@kfshrc.edu.sa

${ }^{1}$ Department of Comparative Medicine, King Faisal Specialist Hospital \& Research Centre, P.O. Box 3354, Riyadh 11211 MBC-03, Kingdom of Saudi Arabia

Full list of author information is available at the end of the article
}

In the recent years, a novel research area has centered on the role of innate immune components-complement cascade in the regulation of Th2-biased adaptive immunity in asthma $[14,18]$. It is well established that uncontrolled complement activation in the airway contributes to asthma pathogenesis, which includes morphogenetic/or pulmonary tissue remodeling $[19,20]$. Complement activation has been demonstrated in mouse models of allergic asthma, which highlighted the role of C3a mediated airway hyperresponsiveness, and airway tissue remodeling [21]. The complement system has also been associated with a variety of non-immunological conditions including pulmonary tissue regeneration, and progression to pulmonary tissue fibrosis after airway tissue injury [22]. The presence of increased levels of C3a and C5a peptides in the bronchoalveolar lavage (BAL) and serum of asthmatics and the increased expression of their respective receptors signifies the key involvement of the complement mediators in asthma pathogenesis [23]. In addition, it has been noted that levels of $C$ reactive protein (CRP) are increased in non-allergic but not in allergic asthma conditions [24]. CRP is an acute-phase serum protein and a mediator of innate immunity through the complement 


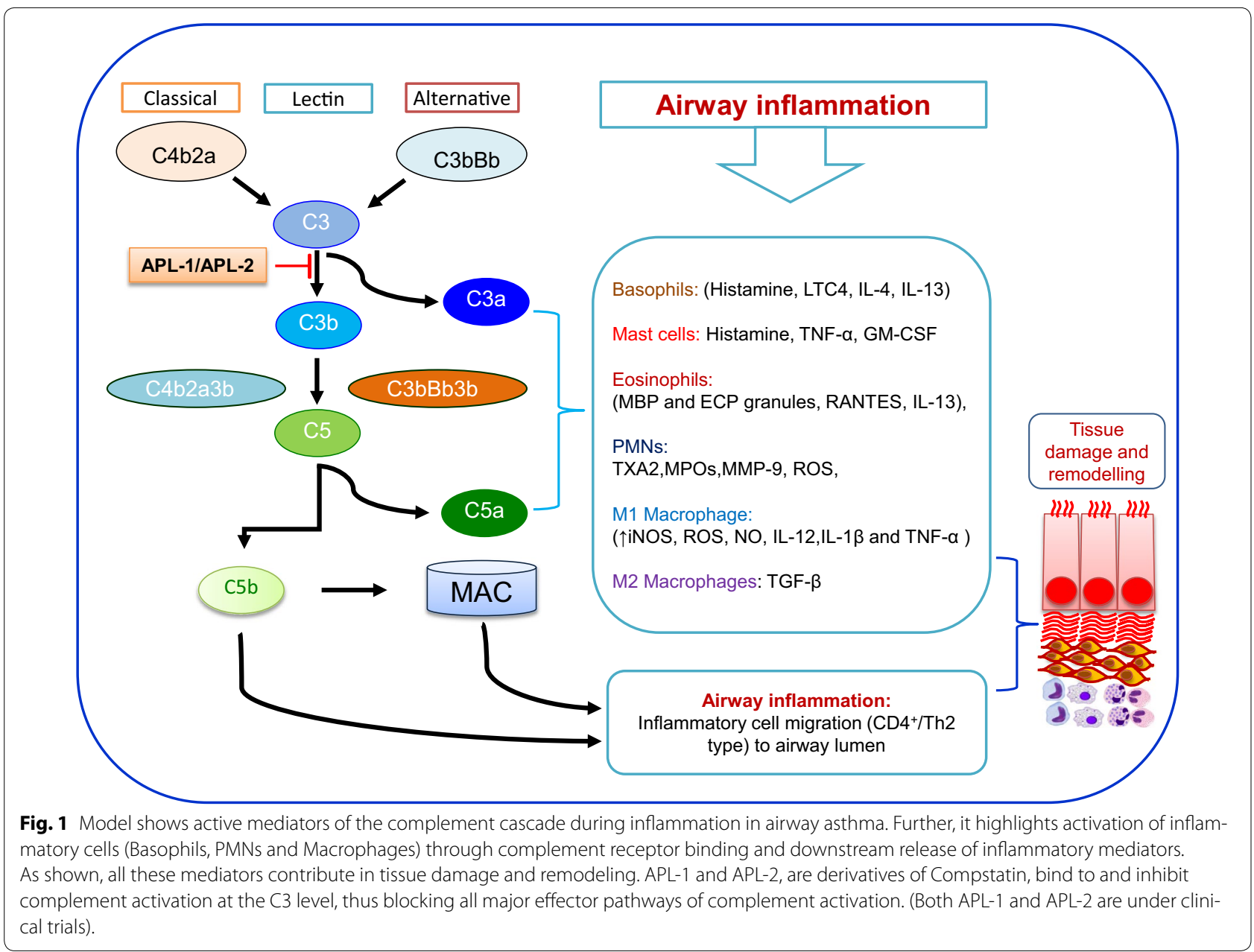

activation of $\mathrm{C} 1, \mathrm{C} 4, \mathrm{C} 2$ and $\mathrm{C} 3$ components. CRP mediates innate immunity through the binding to microbial polysaccharides and to ligands exposed on damaged cells leading to the activation of the classical complement pathway, which facilitates uptake by phagocytic cells $[25,26]$.

The complement cascade comprises a network of active complement mediators of more than 30 proteins, which have been recognized as a major defense option for a host cell against the microbial invaders [19, 27] (Fig. 1). The complement cascade can be initiated through three different pathways: the classical pathway, the lectin pathway, and the alternative pathway. The alternative pathway of the complement cascade plays a vital role in neutrophil-mediated diseases including asthma $[28,29]$. The three pathways all converge in the activation of the pivotal complement molecule $\mathrm{C} 3$ and generate $\mathrm{C} 3$ convertase. This C3 convertase facilitates the cleavage of C3 into C3a and C3b. After cleavage of $\mathrm{C} 3$, the $\mathrm{C} 3 \mathrm{~b}$ molecule combines with the $\mathrm{C} 3$ convertase to form a $\mathrm{C} 4 \mathrm{bC} 2 \mathrm{aC} 3 \mathrm{~b}$ complex in the classical and lectin pathways, while forming a C3bBbC3b complex in the alternative pathway. Both the $\mathrm{C} 4 \mathrm{bC} 2 \mathrm{aC} 3 \mathrm{~b}$ and $\mathrm{C} 3 \mathrm{bBbC3b}$ complexes are known as $\mathrm{C} 5$ convertase, which catalyzes the cleavage of $\mathrm{C} 5$ into $\mathrm{C} 5 \mathrm{a}$ and $\mathrm{C} 5 \mathrm{~b}$ molecules. The generated C5a can then act as a potent anaphylatoxin at the site of production while C5b participate in the assembly of the membrane attack complex (C5b-9 or MAC). The primary cytolytic activity of complement is catalyzed by the non-enzymatic function of the MAC, which is initiated through the amphiphilic complex generated after the linkage of $\mathrm{C} 5 \mathrm{~b}-\mathrm{C} 6$, and $\mathrm{C} 7$. This complex is able to insert into microbial lipid bilayers and subsequent binding of C8 initiates C9 polymerization, which creates membrane-spanning channels to initiate osmotic lysis of the foreign constructs [19] (Fig. 1). In summary, the activated complement mediators in asthma airway tissue remodeling are recognized as a potential targets for therapeutic intervention in preclinical and clinical research [30-32]. This review primarily focus on indirect (thorough adaptive immune system) and direct effects of the complement system on airway tissue remodeling. 


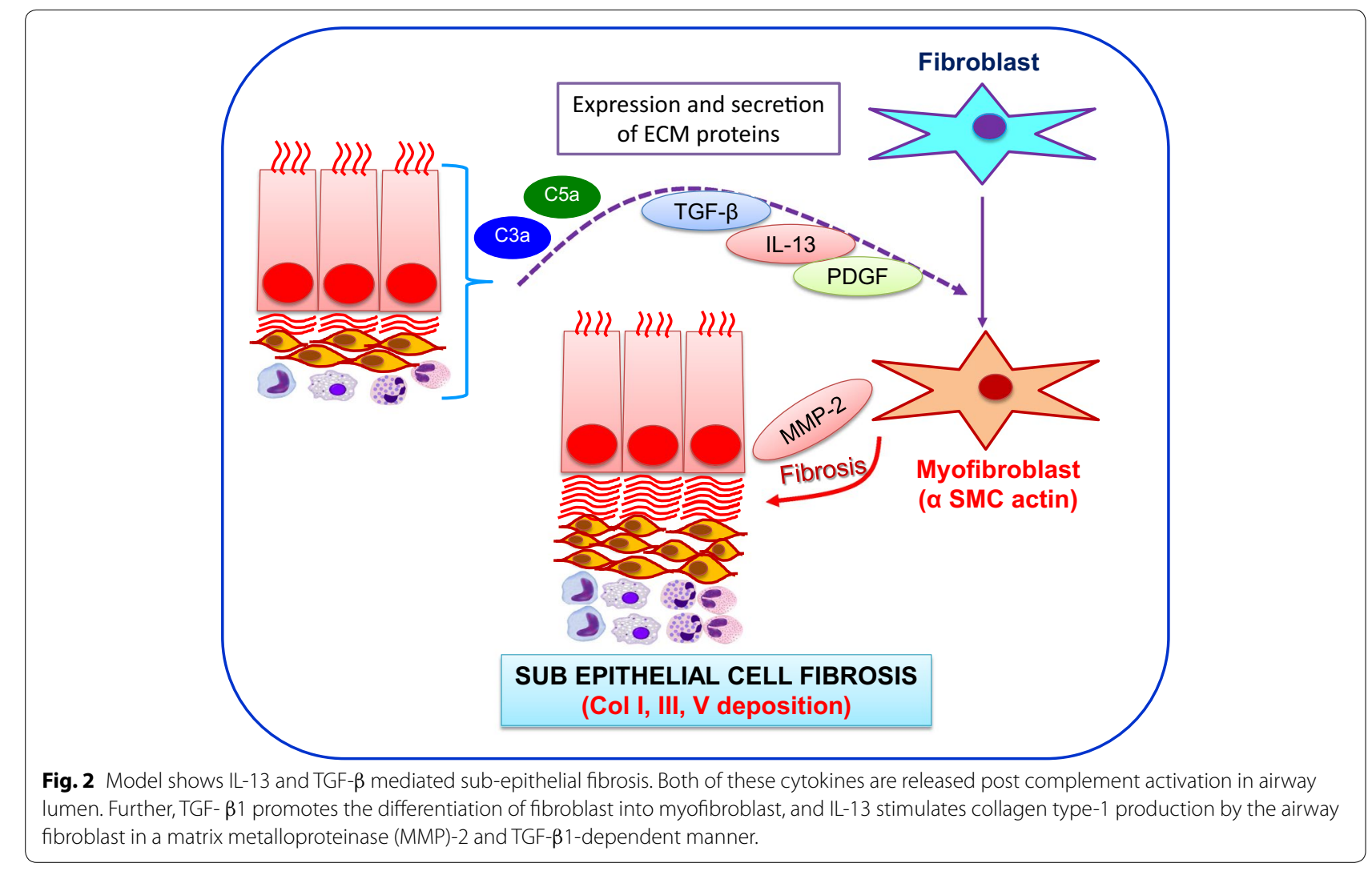

\section{Complement system effect on airway tissue remodeling mediated by adaptive immune system} The complement activation modulates key adoptive immune responses, which stimulates and/or suppress pulmonary allergic reactions during airway tissue remodeling [33]. The complement mediators exerts their immunoregulatory roles through the initiation and development of the adaptive immunity to stimulate and/ or suppress pulmonary allergy in allergic asthma. The involvement of C3a and C5a in asthma is well established, and it is reported that both bronchial epithelial and smooth muscle cells express receptors for C3a and C5a anaphylatoxins $[16,23]$. The core portion of complement activation cascade is involved in host defense against pathogenic infections; however, the by-products C3a and $\mathrm{C} 5 \mathrm{a}$ of the pathway have potent inflammatory properties [15, 34]. In particular, complement components, and their activated fragments $\mathrm{C} 3 \mathrm{a}$ and $\mathrm{C} 5 \mathrm{a}$ synchronize the magnitude of adaptive immune responses via ligation of their respective receptors expressed on antigenpresenting cells (APCs) and T lymphocytes [1, 35-37]. A gradient of inflammatory cytokines released by Th2 cells particularly IL-4, IL-5 and IL-13 coordinates major pulmonary inflammatory responses, which involves development, migration, inflammatory cells activation, allergen-specific antibody production, goblet cell hyperplasia, increase in vascular permeability, and airway reactivity, all of which plays a central role in asthma pathogenesis, and pathology $[4,14,38]$. The genetic interference of complement components in asthma pathogenesis has been investigated, and it is reported that genetic variations in the complement components modulates the susceptibility to asthma [39]. A detailed single nucleotide polymorphisms (SNPs) in C3, C5, C3AR1, and C5AR1 gene plays a significant role in susceptibility and pathogenesis of bronchial asthma [1]. In addition, C3a and C5a modulates Th2 and Th17 immunity as the expression of IL17 by Th17 cell enhances C3 secretion by airway epithelial cells in severe allergic asthma [40].

The anaphylatoxins C5a and C3a have long been credited as a potent pro-inflammatory mediators contributing to the allergic inflammatory conditions [35]. Recent studies indicate that $\mathrm{C} 3 \mathrm{a}$ regulate interaction of APCs and effector cells causing leukocyte activation, smooth muscle contraction, increase in vascular permeability [35, $41]$, inflammatory cell infiltration and mucus secretion $[2,3,16]$.

A wide range of inflammatory cells have been associated with airway tissue remodeling includes lymphocytes, neutrophils, eosinophils, and macrophages, which 
releases various mediators to facilitates airway tissue remodeling process. A variety of cell type produces both mediators, however several studies have identified macrophages as a critical source of both TGF- $\beta 1$ and PDGF in airway fibrosis $[42,43]$. Notably, TGF- $\beta$ is one of the leading mediator involved in airway tissue remodeling during asthmatic pathogenesis. This profibrotic cytokine is secreted by different inflammatory and epithelial cells including ASM, endothelial cells, fibroblasts, macrophages, and eosinophils [44]. TGF- $\beta$ is a potent regulator of fibroblast/myofibroblast function and the production of several ECM proteins including collagens, proteoglycans, and tenascin $[44,45]$. TGF- $\beta 1$ is well known as a key inducer of fibrosis in many tissues and organs [46]. In addition, macrophage also generate profibrotic mediator especially platelet-derived growth factor (PDGF), which directly activate fibroblasts [44, 47]. PDGF act as a potent pro-fibrotic signal by stimulating the proliferation of activated collagen-producing hematopoietic stem cells (HSCs).

\section{Local effects of the complement system on the airway tissue remodeling}

Airway tissue remodeling is a secondary process, which occur due to a chronic inflammatory environment [48, 49]. It disrupts the normal airway tissue repair process, which involves airway wall thickening, mucous hyperplasia, mucosal neovascularization, smooth muscle hyperplasia, deposition of fibrous and other extracellular matrix protein, myofibroblast hyperplasia, epithelial hypertrophy, and mucous gland and goblet cell hyperplasia [48]. Although, the connection between inflammatory process and fibrotic remodeling is well recognized but the origin, mechanism of activation, differentiation of fibroblasts, and the role of different inflammatory cells in asthma is still remain unclear. The relation between complement system and asthma pathogenesis has been previously investigated in different animal model systems [17, $50,51]$. The complement system, with its crucial role in innate and adaptive immunity mediates a variety of effector functions $[3,32,41]$ that play a key roles in airway tissue inflammation and injury. It is a complex cascade involving proteolytic cleavage of anaphylatoxins (C3a and $\mathrm{C} 5 \mathrm{a})$, which are often activated by cell receptors. This cascade ultimately leads to the generation of antibodies and inflammatory responses as well as opsonization of apoptotic and necrotic bodies, facilitating their recognition, clearance, and lysis [20, 27]. C3a and C5a trigger ASM contraction, promote mucus secretion, and augment blood vascular permeability [20, 35]. Furthermore, $\mathrm{C} 5 \mathrm{a}$ and its end-product, membrane attack complex (MAC) regulate the downstream inflammatory responses through the infiltration of inflammatory cells into bronchial airway lumen, which stimulate the release of multiple acute inflammatory mediators TGF- $\beta$, RANTES and Pro MMP-9 $[52,53]$. These inflammatory mediators may induce ASM hypertrophy and collagen deposition under the respiratory epithelium, which leads to the airway tissue remodeling and repair of lower airways [54].

C3a and C5a have potential to activates inflammatory immune cells such as mast cells, macrophages, neutrophils, basophils, eosinophils, and also facilitates enhanced vascular permeability (through bradykinin), and triggers smooth muscle contraction through their receptors [55]. In allergic diseases, $\mathrm{C} 3 \mathrm{a}$ and $\mathrm{C} 5 \mathrm{a}$ mediated $\mathrm{C} 3 \mathrm{aR}$ and $\mathrm{C} 5 \mathrm{aR}$ stimulation respectively produces a series of effector functions ranging from inflammatory cell migration to pro-inflammatory mediator production thus contributing to the development of airway remodeling [56]. Complement receptor-mediated activation of mast cells can occur through CR3 (the receptor for $\mathrm{C} 3 \mathrm{~b}$ ) and C3aR (receptors for C3a); however, degranulation seems to occur mainly as a result of activation of the receptor for C5a (C5aR) [57, 58]. Activated mast cells secrete TNF- $\alpha$, IL- 3 , and GM-CSF, which facilitates downstream activation of neutrophils, eosinophils, and basophils respectively (Fig. 1; Table 1). During eosinophil activation, C3a and $\mathrm{C} 5 \mathrm{a}$ regulate the production of eosinophil cationic protein and their adhesion to endothelial cells as well as their migration [59]. C3a mediate synthesis of IL- 6 and TNF- $\alpha$ from B cells and monocytes, and IL-17A from Th17 cells, which control the severity of experimental asthma [40,60,61]. The anaphylatoxins C3a and C5a generated during complement activation holds numerous pro-inflammatory and immunoregulatory properties critical for development and modulation of allergic immune responses [62]. In addition to its pro-inflammatory effector functions, complement regulates adaptive immunity at many levels $[4,63]$ including increased neutrophilic inflammation in asthma [64].

C5a is a potent chemoattractant for macrophages [65], neutrophils [66], activated B [67] and T cells [68], basophils [69] and mast cells [70]. Complement-induced neutrophil activation mostly involve C5a and possibly C5b-9 complexes identified in serum-activated neutrophils [71]. The products of eosinophil activation, and bindings of $\mathrm{C} 3 \mathrm{a}$ and $\mathrm{C} 5 \mathrm{a}$ have been reported to cause mast cell degranulation in lung tissues, which further regulates the process of inflammation and remodeling [72] (Fig. 2). In addition, C5a has been shown as one of the mediator of pulmonary fibrosis through the release of TGF- $\beta$ and IL-13 by M2 macrophage and eosinophils respectively $[70,73,74]$.

The anaphylatoxins $\mathrm{C} 3 \mathrm{a}$ and $\mathrm{C} 5 \mathrm{a}$ produced during complement cascade activation influence numerous pro-inflammatory and immunoregulatory mediators for 


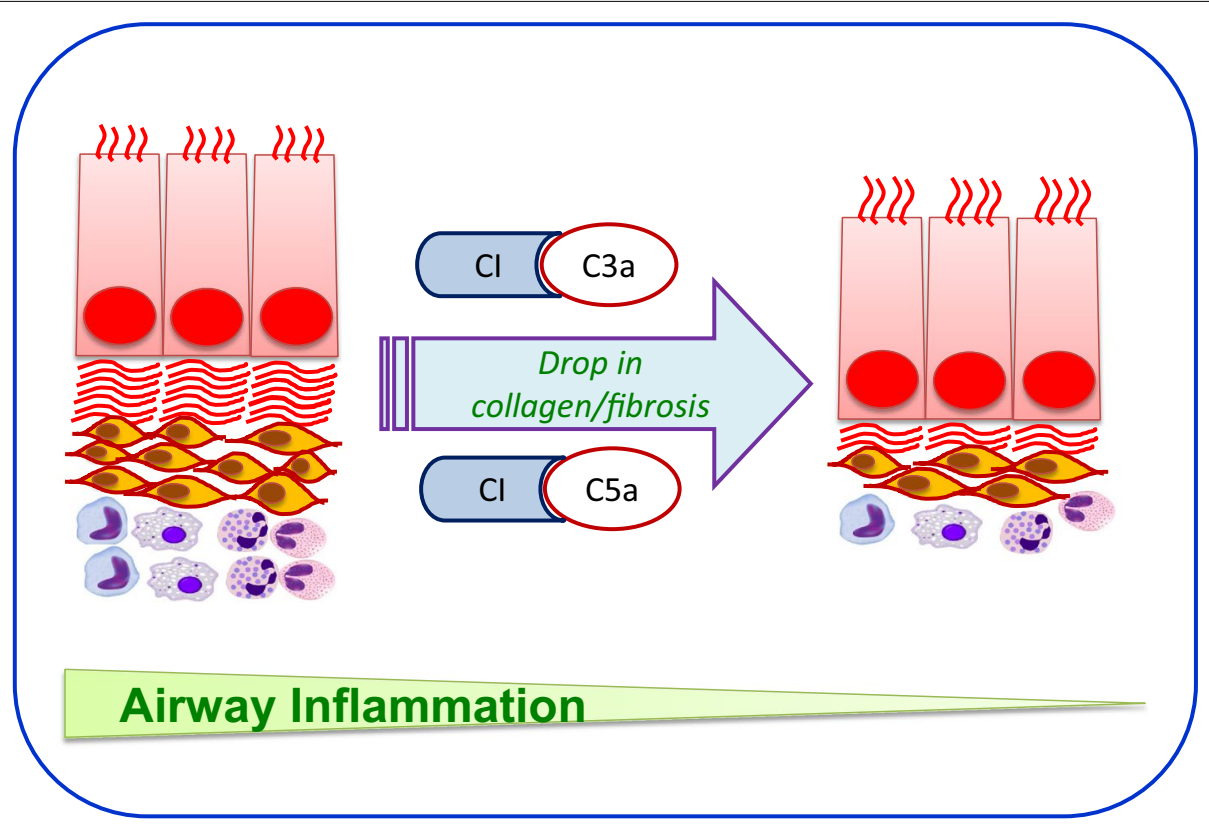

Fig. 3 Simple illustration of complement inhibition approach to prevent fibrosis. This figure shows how blocking C3a and C5a prevent downstream activation of inflammatory mediators and subdue fibrotic process.

Table 1 Signaling through complement mediators and immune cells in airway tissue remodeling

\begin{tabular}{|c|c|c|c|}
\hline Complement & Immune cells & Signaling molecule & Remodeling \\
\hline $\mathrm{C} 3 \mathrm{a}, \mathrm{C5a}$ & M2 macrophages & TGF- $\beta$ & Expression and secretion of ECM proteins \\
\hline $\mathrm{C} 3 \mathrm{a}, \mathrm{C} 5 \mathrm{a}$ & M1 macrophages & $\uparrow$ iNOS, ROS, NO, IL-12, IL-1 $\beta$ and TNF- $\alpha$ & $\begin{array}{l}\text { AHR, airway fibrosis, attraction of eosinophils and neu- } \\
\text { trophils }\end{array}$ \\
\hline $\mathrm{C} 3 \mathrm{a}, \mathrm{C} 5 \mathrm{a}$ & Eosinophil & $\begin{array}{l}\text { MBP and ECP granules, RANTES, IL-13, LTC4, LTC4 and } \\
\text { LTE4, TGF- } \beta\end{array}$ & $\begin{array}{l}\text { Vascular permeability, mucus secretion, and ASM con- } \\
\text { traction, modulation of cellular trafficking }\end{array}$ \\
\hline $\mathrm{C} 3 \mathrm{a}, \mathrm{C} 5 \mathrm{a}$ & Basophils & Histamine, LTC4, IL-4, IL-13 & $\begin{array}{l}\text { ASM contraction, vascular permeability, promotes Th2 } \\
\text { and lgE production }\end{array}$ \\
\hline $\mathrm{C} 3 \mathrm{a}, \mathrm{C} 5 \mathrm{a}$ & PMNs & TXA2, MPOs, MMP-9, ROS & $\begin{array}{l}\text { Bronchoconstriction, stimulate release of serotonin and } \\
\text { histamine through platelets and mast cells respectively. } \\
\text { Vascular permeability, mucus hypersecretion }\end{array}$ \\
\hline $\mathrm{C} 3 \mathrm{a}, \mathrm{C} 5 \mathrm{a}$ & Mast cells & $\begin{array}{l}\text { Histamine, TNF- } \alpha, \text { GM-CSF, IL-4, IL-13 LTC4, } \\
\text { LTB4 and PGD2 }\end{array}$ & $\begin{array}{l}\text { Stimulates ASM contraction, vasodilatation and release } \\
\text { of IL-16 production by CD8+ cells and airway epithelial } \\
\text { cells }\end{array}$ \\
\hline$C 5 b$ and MAC & Th2/CD4+ & $\mathrm{IL}-4, \mathrm{IL}-5$ and IL-13 & $\begin{array}{l}\mathrm{IL}-13 \text { suppress activation of NF-kB, and concomitant IL-5 } \\
\text { induced eosinophilic inflammation in an IL-4- inde- } \\
\text { pendent manner }\end{array}$ \\
\hline
\end{tabular}

the pulmonary tissue-specific immune responses [36] (Table 1). Both C3a and C5a have ability to recruit leukocytic effector cells of the allergic inflammatory response [20]. Of note, C5a is a potent chemo-attractant for cells like macrophages, basophils, neutrophils, and $\mathrm{T}$ lymphocytes, whereas both anaphylatoxins can be chemotactic for eosinophils and mast cells [11]. C3a and C5a also have potency to activate infiltrating granulocytes, leading to speedy production and release of pro-inflammatory mediators, such as histamines, leukotrienes, and platelet-activating factor as well as pro-inflammatory cytokines and chemokines, including IL-1, IL- 6 and TNF- $\alpha$ [75-78]. The generation of functional complement mediators occurs in asthmatic persons, and both C3a and C5a are essential contributors in the pathophysiology of the disease [20]. In asthmatic individuals, a rise in serum C3a and C5a have been reported after allergeninduced bronchospasm [79]. Additionally, the levels of C3a and C5a have been found to increase in the BAL of asthmatic patients after segmental allergen challenge 
[16]. One study found that C3a and C4a concentrations were elevated in the plasma of patients with aspirininduced asthma [80], and numerous other clinical studies has also reported the significant production of anaphylatoxins under asthmatic conditions [18]. However, studies on animal models of airway hyperresponsiveness (AHR) has also concluded that both complement $\mathrm{C} 3 \mathrm{a}$ and $\mathrm{C} 5 \mathrm{a}$ are critical for asthma pathogenesis $[16,23,81]$. In addition to allergen-mediated activation, environmental agents can also triggers the complement activation. Airborne pollutants/or airborne particulate matter can activate the alternative pathway of the complement cascade in human serum and airway epithelium, respectively [34]. Cigarette smoke (CS) has been shown to activate the alternative pathway through cleavage of the internal thioester bond in C3 [82]. C3a also stimulates smooth muscle contraction [83], lysozyme release from immune cells [84], platelet aggregation [85], and triglyceride synthesis in adipocytes [86].

\section{Discussion}

Airway tissue remodeling in asthma is pathologically characterized by subepithelial deposition of collagen in the airways, increase in ASM cell mass, mucus gland hyperplasia, and mucosal neovascularization [48, 87-90]. The process of airway remodeling is potentially a crucial outcome of asthma, and has been associated with the increase in inflammatory cells specially macrophages, neutrophils, basophils and their mediators TGF- $\beta$, iNOS, ROS, NO, IL-12, IL-1 $\beta$, TNF- $\alpha$, TXA2, MPOs, MMP-9, ROS, histamine, LTC4, IL-4, and IL-13, which affect airway structural property and pulmonary functions $[47,74$, 91, 92]. Thus, it is most likely that the process of airway tissue remodeling precede to physiologic subphenotypes of irreversible/or partially reversible airflow obstruction and accelerated lung functions decline associated with the severity of disease [49].

Therapeutically, complement mediators C3a and C5a, and their respective receptors $\mathrm{C} 3 \mathrm{aR}$ and $\mathrm{C} 5 \mathrm{aR}$, displays diverse activities during the course of disease progression and drugs that specifically targets C3a, C3aR, C5, $\mathrm{C} 5 \mathrm{a}$ or $\mathrm{C} 5 \mathrm{aR}$ could serve as potential therapeutic options for asthma treatment in future (Fig. 3) [32]. Experimental findings in mouse model of chronic allergen challenge have demonstrated some of the interesting correlations between airway inflammation, dysfunction and tissue remodeling [93]. The specific roles of complement fragments have been reported in other disease models, e.g. systemic inhibition of $\mathrm{C} 3 \mathrm{a}$ and $\mathrm{C} 5 \mathrm{a}$ resulted in down regulation of collagen have been reported in a mouse model of orthotopic tracheal transplantations [22, 94]. It has been reported that C5-knockouts and C5aR antagonism significantly reduced airway tissue fibrosis at 5 and
10 days post-injury in a mouse model of unilateral urethral obstruction [95]. These investigations in animal models will increasingly allow categorizations of potential mediators resulting in airway tissue remodeling, and their impact on airway physiology [3, 32, 96]. In addition, new complement inhibition based drugs are now under development and shown significant attention in pulmonary diseases in human. In clinical trials, Compstatin, and its derivatives APL- 1 and APL-2 bind to and inhibit complement activation at $\mathrm{C} 3$ activation step, thus blocking all major effector pathways required for complement mediated tissue injury (Fig. 1). C3 inhibition has the potential to make available a broad and effective treatment comparable to further complement inhibition approaches. APL-1, is as a disease-modifying therapy for severe asthma and chronic obstructive pulmonary disease and an inhalable formulation of APL-1 is being used in ongoing Phase 1 trial in the United Kingdom [97, 98]. These studies will rectify efficacy of asthma treatments in reducing airway tissue remodeling in asthma patients. However, additional efforts are necessary in order to uncover the relationship between changes in airway pathology, and physiology before treatment regimens to prevent/or resolve established tissue airway remodeling. In new drug development for asthma therapy, the overwhelming interest of various highly specific complement inhibitors (C3a and C5a) for the demonstration of pathological mechanisms may not only uncover new candidates with therapeutic potential but also help discover even more fascinating cross-talk mechanisms between complement and other cellular parts of immunity.

In summary, this review discussed the complementmediated airway tissue injury, remodeling in airway epithelium, and we anticipate that blocking/or antagonism of the functioning complement mediators could act as a potential therapeutic strategy to salvage asthma patients.

\section{Conclusions}

This review contributes to distinguish direct effects of the complement system on biological processes associated with airway tissue remodeling from indirect effects caused by adaptive immunity. Of note, this review highlights that complex functional changes in airways coexist with the complex inflammatory processes, and the potential synergistic use of C3a and C5a inhibition may subdue airway inflammation and prevent subepithelial fibrosis by blocking the intrapulmonary activation of $\mathrm{C} 3 \mathrm{a}$ and $\mathrm{C} 5 \mathrm{a}$, is a potential clinical approach for treating patients with asthma.

\section{Abbreviations}

APL-1 and -2: novel complement inhibitors of Apellis pharma; AHR: airway hyperresponsiveness; ASM: airway smooth muscle; BAL: bronchoalveolar 
lavage; C3AR1: complement component 3a receptor 1; C5AR1: complement component 5 a receptor 1 ; Cl: complement inhibitors; CRP: $\mathrm{C}$ reactive protein; CS: cigarette smoke; ECM: extra cellular matrix; ECP: eosinophil cationic protein; HSCs: hematopoietic stem cells; MPOs: myeloperoxidase; NO: nitric oxide; iNOS: inducible nitric oxide synthetase; PDGF: platelet-derived growth factor; PGD2: prostaglandin D2; Pro MMP-9: matrix metallopeptidase 9 (Type IV collagenase); RANTES: regulated on activation, normal T cell expressed and secreted; ROS: reactive oxygen species; TXA2: thromboxane A2.

\section{Authors' contributions}

MAK has been involved in writing, compiling the manuscript, and in revising it critically for publication standards; AMA and DCB contributed significantly on literature and critical suggestions to reshape the manuscript. All authors read and approved the final version of manuscript.

\section{Author details}

${ }^{1}$ Department of Comparative Medicine, King Faisal Specialist Hospital \& Research Centre, P.O. Box 3354, Riyadh 11211 MBC-03, Kingdom of Saudi Arabia. ${ }^{2}$ Organ Transplant Centre, King Faisal Specialist Hospital \& Research Centre, Riyadh, Kingdom of Saudi Arabia.

\section{Acknowledgements}

The authors would like to thanks Dr. Suhail Akhtar (sakhtar@luriechildrens.org), Stanley Manne Children's Research Institute, Chicago, USA, for critically reading this manuscript.

\section{Compliance with ethical guidelines}

\section{Competing interest}

The authors declare that they have no competing interest.

Received: 28 January 2015 Accepted: 3 June 2015

Published online: 20 August 2015

\section{References}

1. Hasegawa K, Tamari M, Shao C, Shimizu M, Takahashi N, Mao XQ et al (2004) Variations in the C3, C3a receptor, and C5 genes affect susceptibility to bronchial asthma. Hum Genet 115:295-301

2. Thangam EB, Venkatesha RT, Zaidi AK, Jordan-Sciutto KL, Goncharov DA, Krymskaya VP et al (2005) Airway smooth muscle cells enhance C3a-induced mast cell degranulation following cell-cell contact. FASEB J 19:798-800

3. Khan MA (2013) Inflammation signals airway smooth muscle cell proliferation in asthma pathogenesis. Multidiscip Respir Med 8:11

4. Barnes PJ, Chung KF, Page CP (1998) Inflammatory mediators of asthma: an update. Pharmacol Rev 50:515-596

5. Cho SH, Stanciu LA, Holgate ST, Johnston SL (2005) Increased interleukin-4, interleukin-5, and interferon-gamma in airway CD4+ and CD8+ T cells in atopic asthma. Am J Respir Crit Care Med 171:224-230

6. Huang TJ, MacAry PA, Kemeny DM, Chung KF (1999) Effect of CD8+ T-cell depletion on bronchial hyper-responsiveness and inflammation in sensitized and allergen-exposed Brown-Norway rats. Immunology 96:416-423

7. Couto Alves A, Bruhn S, Ramasamy A, Wang H, Holloway JW, Hartikainen AL et al (2013) Dysregulation of complement system and CD4+ T cell activation pathways implicated in allergic response. PLoS One 8:e74821

8. Lazaar AL, Panettieri RA Jr (2001) Airway smooth muscle as an immunomodulatory cell: a new target for pharmacotherapy? Curr Opin Pharmacol 1:259-264

9. Saglani S, Lloyd CM (2014) Eosinophils in the pathogenesis of paediatric severe asthma. Curr Opin Allergy Clin Immunol 14:143-148

10. Hogan SP, Rosenberg HF, Mogbel R, Phipps S, Foster PS, Lacy P et al (2008) Eosinophils: biological properties and role in health and disease. Clin Exp Allergy 38:709-750

11. Guo RF, Ward PA (2005) Role of C5a in inflammatory responses. Annu Rev Immunol 23:821-852

12. Jatakanon A, Uasuf C, Maziak W, Lim S, Chung KF, Barnes PJ (1999) Neutrophilic inflammation in severe persistent asthma. Am J Respir Crit Care Med 160:1532-1539
13. Hart PH (2001) Regulation of the inflammatory response in asthma by mast cell products. Immunol Cell Biol 79:149-153

14. Caramori G, Ito K, Adcock IM (2004) Targeting Th2 cells in asthmatic airways. Curr Drug Targets Inflamm Allergy 3:243-255

15. Ali H, Panettieri RA Jr (2005) Anaphylatoxin C3a receptors in asthma. Respir Res 6:19

16. Drouin SM, Kildsgaard J, Haviland J, Zabner J, Jia HP, McCray PB Jr et al (2001) Expression of the complement anaphylatoxin C3a and C5a receptors on bronchial epithelial and smooth muscle cells in models of sepsis and asthma. J Immunol 166:2025-2032

17. Zhang $X$, Schmudde I, Laumonnier Y, Pandey MK, Clark JR, Konig P et al (2010) A critical role for C5L2 in the pathogenesis of experimental allergic asthma. J Immunol 185:6741-6752

18. Kohl J, Baelder R, Lewkowich IP, Pandey MK, Hawlisch H, Wang L et al (2006) A regulatory role for the C5a anaphylatoxin in type 2 immunity in asthma. J Clin Invest 116:783-796

19. Wills-Karp M (2007) Complement activation pathways: a bridge between innate and adaptive immune responses in asthma. Proc Am Thorac Soc 4:247-251

20. Zhang $X$, Kohl J (2010) A complex role for complement in allergic asthma. Expert Rev Clin Immunol 6:269-277

21. Mizutani N, Nabe T, Yoshino S (2009) Complement C3a regulates late asthmatic response and airway hyperresponsiveness in mice. J Immunol 183:4039-4046

22. Khan MA, Maasch C, Vater A, Klussmann S, Morser J, Leung LL et al (2013) Targeting complement component 5 a promotes vascular integrity and limits airway remodeling. Proc Natl Acad Sci USA 110:6061-6066

23. Krug N, Tschernig T, Erpenbeck VJ, Hohlfeld JM, Kohl J (2001) Complement factors $\mathrm{C} 3 \mathrm{a}$ and $\mathrm{C} 5 \mathrm{a}$ are increased in bronchoalveolar lavage fluid after segmental allergen provocation in subjects with asthma. Am J Respir Crit Care Med 164:1841-1843

24. Olafsdottir IS, Gislason T, Thjodleifsson B, Olafsson I, Gislason D, Jogi R et al (2005) C reactive protein levels are increased in non-allergic but not allergic asthma: a multicentre epidemiological study. Thorax 60:451-454

25. Mold C (1999) Role of complement in host defense against bacterial infection. Microbes Infect 1:633-638

26. Mold C, Gewurz H, Du Clos TW (1999) Regulation of complement activation by C-reactive protein. Immunopharmacology 42:23-30

27. Glovsky MM, Ward PA, Johnson KJ (2004) Complement determinations in human disease. Ann Allergy Asthma Immunol 93:513-522 (Quiz 523-515, 605)

28. Fayyazi A, Sandau R, Duong LQ, Gotze O, Radzun HJ, Schweyer S et al (1999) C5a receptor and interleukin-6 are expressed in tissue macrophages and stimulated keratinocytes but not in pulmonary and intestinal epithelial cells. Am J Pathol 154:495-501

29. Rutkowski MJ, Sughrue ME, Kane AJ, Ahn BJ, Fang S, Parsa AT (2010) The complement cascade as a mediator of tissue growth and regeneration. Inflamm Res 59:897-905

30. Lukacs NW, Glovsky MM, Ward PA (2001) Complement-dependent immune complex-induced bronchial inflammation and hyperreactivity. Am J Physiol Lung Cell Mol Physiol 280:L512-L518

31. Ricklin D, Hajishengallis G, Yang K, Lambris JD (2010) Complement: a key system for immune surveillance and homeostasis. Nat Immunol 11:785-797

32. Khan MA, Nicolls MR, Surguladze B, Saadoun I (2014) Complement components as potential therapeutic targets for asthma treatment. Respir Med 108:543-549

33. Hawlisch H, Wills-Karp M, Karp CL, Kohl J (2004) The anaphylatoxins bridge innate and adaptive immune responses in allergic asthma. Mol Immunol 41:123-131

34. Walters DM, Breysse PN, Schofield B, Wills-Karp M (2002) Complement factor 3 mediates particulate matter-induced airway hyperresponsiveness. Am J Respir Cell Mol Biol 27:413-418

35. Humbles AA, Lu B, Nilsson CA, Lilly C, Israel E, Fujiwara Y et al (2000) A role for the C3a anaphylatoxin receptor in the effector phase of asthma. Nature 406:998-1001

36. Kohl J, Wills-Karp M (2007) A dual role for complement in allergic asthma. Curr Opin Pharmacol 7:283-289

37. Banda NK, Hyatt S, Antonioli AH, White JT, Glogowska M, Takahashi K et al (2012) Role of C3a receptors, C5a receptors, and complement protein C6 deficiency in collagen antibody-induced arthritis in mice. J Immunol 188:1469-1478 
38. Bousquet J, Jeffery PK, Busse WW, Johnson M, Vignola AM (2000) Asthma. From bronchoconstriction to airways inflammation and remodeling. Am J Respir Crit Care Med 161:1720-1745

39. Clarke JR, Jenkins MA, Hopper JL, Carlin JB, Mayne C, Clayton DG et al (2000) Evidence for genetic associations between asthma, atopy, and bronchial hyperresponsiveness: a study of 8- to 18-yr-old twins. Am J Respir Crit Care Med 162:2188-2193

40. Lajoie S, Lewkowich IP, Suzuki Y, Clark JR, Sproles AA, Dienger K et al (2010) Complement-mediated regulation of the IL-17A axis is a central genetic determinant of the severity of experimental allergic asthma. Nat Immunol 11:928-935

41. Stimler NP, Hugli TE, Bloor CM (1980) Pulmonary injury induced by C3a and C5a anaphylatoxins. Am J Pathol 100:327-348

42. Wynn TA, Barron L (2010) Macrophages: master regulators of inflammation and fibrosis. Semin Liver Dis 30:245-257

43. Kenyon NJ, Ward RW, McGrew G, Last JA (2003) TGF-beta1 causes airway fibrosis and increased collagen I and III mRNA in mice. Thorax 58:772-777

44. Flood-Page P, Menzies-Gow A, Phipps S, Ying S, Wangoo A, Ludwig MS et al (2003) Anti-IL-5 treatment reduces deposition of ECM proteins in the bronchial subepithelial basement membrane of mild atopic asthmatics. J Clin Invest 112:1029-1036

45. Phipps S, Ying S, Wangoo A, Ong YE, Levi-Schaffer F, Kay AB (2002) The relationship between allergen-induced tissue eosinophilia and markers of repair and remodeling in human atopic skin. J Immunol 169:4604-4612

46. Murray PJ, Wynn TA (2011) Protective and pathogenic functions of macrophage subsets. Nat Rev Immunol 11:723-737

47. Kelley J, Kovacs EJ, Nicholson K, Fabisiak JP (1991) Transforming growth factor-beta production by lung macrophages and fibroblasts. Chest 99:85S-86S

48. Bergeron C, Tulic MK, Hamid Q (2010) Airway remodelling in asthma: from benchside to clinical practice. Can Respir J 17:e85-e93

49. Shifren A, Witt C, Christie C, Castro M (2012) Mechanisms of remodeling in asthmatic airways. J Allergy (Cairo) 2012:316049

50. Reddy AT, Lakshmi SP, Reddy RC (2012) Murine model of allergen induced asthma. J Vis Exp (63):e3771

51. Takeda K, Thurman JM, Tomlinson S, Okamoto M, Shiraishi Y, Ferreira VP et al (2012) The critical role of complement alternative pathway regulator factor $\mathrm{H}$ in allergen-induced airway hyperresponsiveness and inflammation. J Immunol 188:661-667

52. Peng Q, Li K, Anderson K, Farrar CA, Lu B, Smith RA et al (2008) Local production and activation of complement up-regulates the allostimulatory function of dendritic cells through C3a-C3aR interaction. Blood 111:2452-2461

53. Peng T, Hao L, Madri JA, Su X, Elias JA, Stahl GL et al (2005) Role of C5 in the development of airway inflammation, airway hyperresponsiveness, and ongoing airway response. J Clin Invest 115:1590-1600

54. Boulet LP, Turcotte H, Laviolette M, Naud F, Bernier MC, Martel S et al (2000) Airway hyperresponsiveness, inflammation, and subepithelial collagen deposition in recently diagnosed versus long-standing mild asthma. Influence of inhaled corticosteroids. Am J Respir Crit Care Med 162:1308-1313

55. Wust SK, Blumenthal MN, Corazalla EO, Benson BA, Dalmasso AP (2006) Complement in asthma: sensitivity to activation and generation of C $3 \mathrm{a}$ and $\mathrm{C} 5 \mathrm{a}$ via the different complement pathways. Transl Res 148:157-163

56. Baelder R, Fuchs B, Bautsch W, Zwirner J, Kohl J, Hoymann HG et al (2005) Pharmacological targeting of anaphylatoxin receptors during the effector phase of allergic asthma suppresses airway hyperresponsiveness and airway inflammation. J Immunol 174:783-789

57. Fureder W, Agis H, Willheim M, Bankl HC, Maier U, Kishi K et al (1995) Differential expression of complement receptors on human basophils and mast cells. Evidence for mast cell heterogeneity and CD88/C5aR expression on skin mast cells. J Immunol 155:3152-3160

58. Nilsson G, Johnell M, Hammer CH, Tiffany HL, Nilsson K, Metcalfe DD et al (1996) C3a and C5a are chemotaxins for human mast cells and act through distinct receptors via a pertussis toxin-sensitive signal transduction pathway. J Immunol 157:1693-1698

59. DiScipio RG, Daffern PJ, Jagels MA, Broide DH, Sriramarao P (1999) A comparison of $\mathrm{C} 3 \mathrm{a}$ and $\mathrm{C} 5 \mathrm{a}$-mediated stable adhesion of rolling eosinophils in postcapillary venules and transendothelial migration in vitro and in vivo. J Immunol 162:1127-1136
60. Fischer WH, Jagels MA, Hugli TE (1999) Regulation of IL-6 synthesis in human peripheral blood mononuclear cells by C3a and C3a(desArg). J Immunol 162:453-459

61. Mathews JA, Wurmbrand AP, Ribeiro L, Neto FL, Shore SA (2014) Induction of IL-17A precedes development of airway hyperresponsiveness during diet-induced obesity and correlates with complement factor D. Front Immunol 5:440

62. Chung KF, Barnes PJ (1999) Cytokines in asthma. Thorax 54:825-857

63. Barnes PJ (1998) Anti-inflammatory actions of glucocorticoids: molecular mechanisms. Clin Sci (Lond) 94:557-572

64. Jatakanon A, Lalloo UG, Lim S, Chung KF, Barnes PJ (1999) Increased neutrophils and cytokines, TNF-alpha and IL-8, in induced sputum of non-asthmatic patients with chronic dry cough. Thorax 54:234-237

65. Aksamit RR, FalkW, Leonard EJ (1981) Chemotaxis by mouse macrophage cell lines. J Immunol 126:2194-2199

66. Ehrengruber MU, Geiser T, Deranleau DA (1994) Activation of human neutrophils by $\mathrm{C} 3 \mathrm{a}$ and $\mathrm{C} 5 \mathrm{~A}$. Comparison of the effects on shape changes, chemotaxis, secretion, and respiratory burst. FEBS Lett 346:181-184

67. Ottonello L, Corcione A, Tortolina G, Airoldi I, Albesiano E, Favre A et al (1999) rC5a directs the in vitro migration of human memory and naive tonsillar B lymphocytes: implications for B cell trafficking in secondary lymphoid tissues. J Immunol 162:6510-6517

68. Nataf S, Davoust N, Ames RS, Barnum SR (1999) Human T cells express the C5a receptor and are chemoattracted to C5a. J Immunol 162:4018-4023

69. Lett-Brown MA, Leonard EJ (1977) Histamine-induced inhibition of normal human basophil chemotaxis to C5a. J Immunol 118:815-818

70. Hartmann K, Henz BM, Kruger-Krasagakes S, Kohl J, Burger R, Guhl S et al (1997) C3a and C5a stimulate chemotaxis of human mast cells. Blood 89:2863-2870

71. Camous L, Roumenina L, Bigot S, Brachemi S, Fremeaux-Bacchi V, Lesavre $P$ et al (2011) Complement alternative pathway acts as a positive feedback amplification of neutrophil activation. Blood 117:1340-1349

72. He SH, Zhang HY, Zeng XN, Chen D, Yang PC (2013) Mast cells and basophils are essential for allergies: mechanisms of allergic inflammation and a proposed procedure for diagnosis. Acta Pharmacol Sin 34:1270-1283

73. Fick RB Jr, Robbins RA, Squier SU, Schoderbek WE, Russ WD (1986) Complement activation in cystic fibrosis respiratory fluids: in vivo and in vitro generation of C5a and chemotactic activity. Pediatr Res 20:1258-1268

74. Murray LA, Argentieri RL, Farrell FX, Bracht M, Sheng H, Whitaker B et al (2008) Hyper-responsiveness of IPF/UIP fibroblasts: interplay between TGFbeta1, IL-13 and CCL2. Int J Biochem Cell Biol 40:2174-2182

75. Wills-Karp M, Koehl J (2005) New insights into the role of the complement pathway in allergy and asthma. Curr Allergy Asthma Rep 5:362-369

76. el-Lati SG, Dahinden CA, Church MK (1994) Complement peptides C3aand $\mathrm{C5}$ a-induced mediator release from dissociated human skin mast cells. J Invest Dermatol 102:803-806

77. Takafuji S, Tadokoro K, Ito K, Dahinden CA (1994) Degranulation from human eosinophils stimulated with C3a and C5a. Int Arch Allergy Immunol 104(Suppl 1):27-29

78. Monsinjon T, Gasque P, Chan P, Ischenko A, Brady JJ, Fontaine MC (2003) Regulation by complement C3a and C5a anaphylatoxins of cytokine production in human umbilical vein endothelial cells. FASEB J 17:1003-1014

79. Arroyave CM, Stevenson DD, Vaughan JH, Tan EM (1977) Plasma complement changes during bronchospasm provoked in asthmatic patients. Clin Allergy 7:173-182

80. Lee SH, Rhim T, Choi YS, Min JW, Kim SH, Cho SY et al (2006) Complement C3a and C4a increased in plasma of patients with aspirin-induced asthma. Am J Respir Crit Care Med 173:370-378

81. Krug N, Erpenbeck VJ, Balke K, Petschallies J, Tschernig T, Hohlfeld JM et al (2001) Cytokine profile of bronchoalveolar lavage-derived CD4(+), CD8(+), and gammadelta T cells in people with asthma after segmental allergen challenge. Am J Respir Cell Mol Biol 25:125-131

82. Kew RR, Ghebrehiwet B, Janoff A (1987) Characterization of the third component of complement (C3) after activation by cigarette smoke. Clin Immunol Immunopathol 44:248-258

83. Stimler NP, Bloor CM, Hugli TE (1983) C3a-induced contraction of guinea pig lung parenchyma: role of cyclooxygenase metabolites. Immunopharmacology 5:251-257

84. Showell HJ, Glovsky MM, Ward PA (1982) C3a-induced lysosomal enzyme secretion from human neutrophils: lack of inhibition by $\mathrm{f}$ met-leu-phe antagonists and inhibition by arachidonic acid antagonists. Int Arch Allergy Appl Immunol 67:227-232 
85. Becker S, Meuer S, Hadding U, Bitter-Suermann D (1978) Platelet activation: a new biological activity of guinea-pig C3a anaphylatoxin. Scand J Immunol 7:173-180

86. Baldo A, Sniderman AD, St-Luce S, Avramoglu RK, Maslowska M, Hoang B et al (1993) The adipsin-acylation stimulating protein system and regulation of intracellular triglyceride synthesis. J Clin Invest 92:1543-1547

87. Boulet LP, Sterk PJ (2007) Airway remodelling: the future. Eur Respir J 30:831-834

88. Fixman ED, Stewart A, Martin JG (2007) Basic mechanisms of development of airway structural changes in asthma. Eur Respir J 29:379-389

89. Aikawa T, Shimura S, Sasaki H, Ebina M, Takishima T (1992) Marked goblet cell hyperplasia with mucus accumulation in the airways of patients who died of severe acute asthma attack. Chest 101:916-921

90. Li X, Wilson JW (1997) Increased vascularity of the bronchial mucosa in mild asthma. Am J Respir Crit Care Med 156:229-233

91. Ameredes BT, Zamora R, Gibson KF, Billiar TR, Dixon-McCarthy B, Watkins S et al (2001) Increased nitric oxide production by airway cells of sensitized and challenged IL-10 knockout mice. J Leukoc Biol 70:730-736

92. Cataldo D, Munaut C, Noel A, Frankenne F, Bartsch P, Foidart JM et al (2000) MMP-2- and MMP-9-linked gelatinolytic activity in the sputum from patients with asthma and chronic obstructive pulmonary disease. Int Arch Allergy Immunol 123:259-267
93. Lloyd CM, Robinson DS (2007) Allergen-induced airway remodelling. Eur Respir J 29:1020-1032

94. Khan MA, Jiang X, Dhillon G, Beilke J, Holers VM, Atkinson C et al (2011) $\mathrm{CD} 4+\mathrm{T}$ cells and complement independently mediate graft ischemia in the rejection of mouse orthotopic tracheal transplants. Circ Res 109:1290-1301

95. Danobeitia JS, Djamali A, Fernandez LA (2014) The role of complement in the pathogenesis of renal ischemia-reperfusion injury and fibrosis. Fibrogenesis Tissue Repair 7:16

96. Khan MA, Nicolls MR (2013) Complement-mediated microvascular injury leads to chronic rejection. Adv Exp Med Biol 734:233-246

97. Ricklin D, Lambris JD (2013) Complement in immune and inflammatory disorders: therapeutic interventions. J Immunol 190:3839-3847

98. Ricklin D, Lambris JD (2013) Progress and trends in complement therapeutics. Adv Exp Med Biol 735:1-22

\section{Submit your next manuscript to BioMed Central and take full advantage of:}

- Convenient online submission

- Thorough peer review

- No space constraints or color figure charges

- Immediate publication on acceptance

- Inclusion in PubMed, CAS, Scopus and Google Scholar

- Research which is freely available for redistribution

Submit your manuscript at 